\title{
Research Aвticle: Training needs of Osmanabadi goat rearers in Marathwada region
}

Article Chronicle : Received : 10.07.2017;

Accepted :

25.07.2017

KEY WORDS:

Goat, Joint family, Social participation, Milk

\section{S.G. KHOBARE, D.D. SURADKAR AND D.D. NIGADE}

SUMMARY : The present study was conducted with specific objectives to study the "Training Needs of Osmanabadi goat rearers in Marathwada region". Majority of goat rearers belonged to middle age category, had education upto primary level,medium level of experience in goat keeping, big family size, more than half of the goat rearers belonged to category of joint family, medium flock size, small size of land holding, medium level of annual income, medium use of sources of information, low level of social participation and had medium knowledge.The characteristics viz., age, experience in goat keeping, family size, was negatively significant with their training needs. While education, family type, flock size of goat, use of sources of information, knowledge had positively and highly significant relationship with their training need.Whereas annual income, social participation had positive and significant relationship with their training needs.Size of land holding was non-significant relationship with their training needs.

How to cite this article : Khobare, S.G., Suradkar, D.D.and Nigade, D.D. (2017). Training needs of Osmanabadi goat rearers in Marathwada region. Agric. Update, 12(TECHSEAR-3) : 713-717; DOI: 10.15740/HAS/AU/ 12.TECHSEAR(3)2017/713-717.
Author for correspondence :

\section{S.G. KHOBARE}

College of Agriculture (VNMKV), LATUR (M.S.) INDIA

See end of the article for authors' affiliations 